\title{
AN EXPERIMENTAL STUDY OF STUDENT'S ATTITUDE TOWARDS THE ADOPTION OF MOBILE SHOPPING WITH MILLENNIALS
}

\author{
V. Geetha ${ }^{*}$, V. Samuel Rajkumar ${ }^{2}$ \\ ${ }^{1}$ Research Scholar, VIT Business School, VIT University, Vellore, India, ${ }^{2}$ Professor, VIT Business School, VIT \\ University, Vellore, India. \\ Email: ${ }^{1 *}$ geetha.v2015@ vit.ac.in, ${ }^{2}$ sam.rajkumar@vit.ac.in
}

Article History: Received on $27^{\text {th }}$ November 2019, Revised on $25^{\text {th }}$ March 2020, Published on $03^{\text {rd }}$ April 2020

\begin{abstract}
Purpose of the study: An increasing usage Web in India offers online purchasing opportunities and it has become a popular marketing channel. To open the way for the latest concept called mobile commerce, it created the other catch up. Generally buying intention, offline or online is highly influenced by customer attitude. In the context of mobile shopping, the aim of this present study continues to analyze the variables which influence the attitude of the student towards buying intention.
\end{abstract}

Methodology: This work is quantitative and focused on primary data collected from an online survey from the young millionaire who is all Smartphone users. Based on TAM and UTAUT2 we adopted and modify the model and it was tested on the information set of 533 samples by smart PLS 2.0.

Main Findings: The statistical results revealed which performance expectancy, Facilitating condition and social influence have a direct positive effect on attitude. Moreover, the attitude was positively related to Purchase intention among young millionaire. Finally, the research result is analyzed and discussed. Implications are highlighted for the current study and research along with limitations and directions for the future are pointed out.

Applications of this study: This article includes particle mobile shopping in India, and it is will promote huge contributions in mobile commerce research.

Novelty/Originality of this study: The existing studies survey indicates that a variety of variables were studied in the sense of millennials ' mobile shopping adoption and limited success has been published on these factors. Furthermore, the study has been done to examine millennial attitudes towards mobile shopping adoption and especially to study factors that can influence millennials' shopping attitudes through mobile internet.

Keywords: Mobile Commerce, Mobile Shopping, Attitude, Purchase Intention, Millennials, UTAUT2, Smart PLS 2.O.

\section{INTRODUCTION}

Andreas Kaplan, a professor and specialist of marketing, defines mobile marketing as, "any marketing activity conducted through a ubiquitous network to which consumers are constantly using a personal mobile device". Finland is a "birthplace" of Mobile Commerce. It was developed in late 1997 by Kevin Duffey. Mobile commerce varies from electronic commerce and it has unique features as "user mobility" which makes mobile commerce energetically depend on the place in which the mobile user operates.

In the current mobile commerce landscape, business models appliance diverse applications based on a variety of platforms. The "true" mobility factors are "ubiquity", "timeliness" and "localization". Lee and Ho (2010), the growth of mobile communications and information systems and the frequency of mobile devices (e.g. cell phones, private electronic support, and tablet PCs), Internet access as well as other communications systems are no longer controlled in the conventional static windows environment. Nagi and Gunasekaran (2007), Mobile commerce can view as a subclass of electronic commerce. Lee and Wong (2016), mobile commerce defined as "any transaction, involving the transfer of ownership or rights to use goods and services, which is initiated and/or completed by using mobiles access to computermediated networks with the help of mobile devices". Marimon et al. (2015), specified the consumer are classified into various types as convenience shopper, variety seeker, the balanced buyer, and the store oriented shopper. Ryu (2013), the best mobile communication approach is a pull strategy, in which marketing messages are transferred through other objects or media that pull or induce consumers to access the messages. The Internet has altered the way customers store and purchase products and services due to the change in the telecom industry.

Online shopping in India is affected by its reputation, brand image, and distinctive advertising strategies. Mobile applications from various industries such as travel, food and banking, shopping education, transport, health care, home services, and payments are attractive to one another. Lee et al. (2005), the development of mobile commerce collaboration has facilitated by both private and public sectors. They are offering discounts, coupons, adding credits or services in contradiction of application connects and initial purchase merely appeal only to the mobile business. Muthukumar and Muthu (2015), More than 25\% of all online shopping deals will take place in the mobile mode by the year 2017. There is no doubt that mobile commerce has been a challenging sales medium. Billions of people connect with their preferred companies through their phones, and enterprises have been participating in transforming these interactions into sales. The global setting system allows a retailer to know the meticulous locality of its customers. Such technology gives them a better understanding of the needs of their target audience. 


\section{MOBILE INTERNET USERS GROWING AT FAST CLIP}

\author{
$>$ In 2017, 320.6 million people \\ accessed the internet on their \\ mobile phones
}

\author{
$>$ In 2022, this figure is projected \\ to amount to 492.7 million mobile \\ phone internet users, a rise of $54 \%$
}

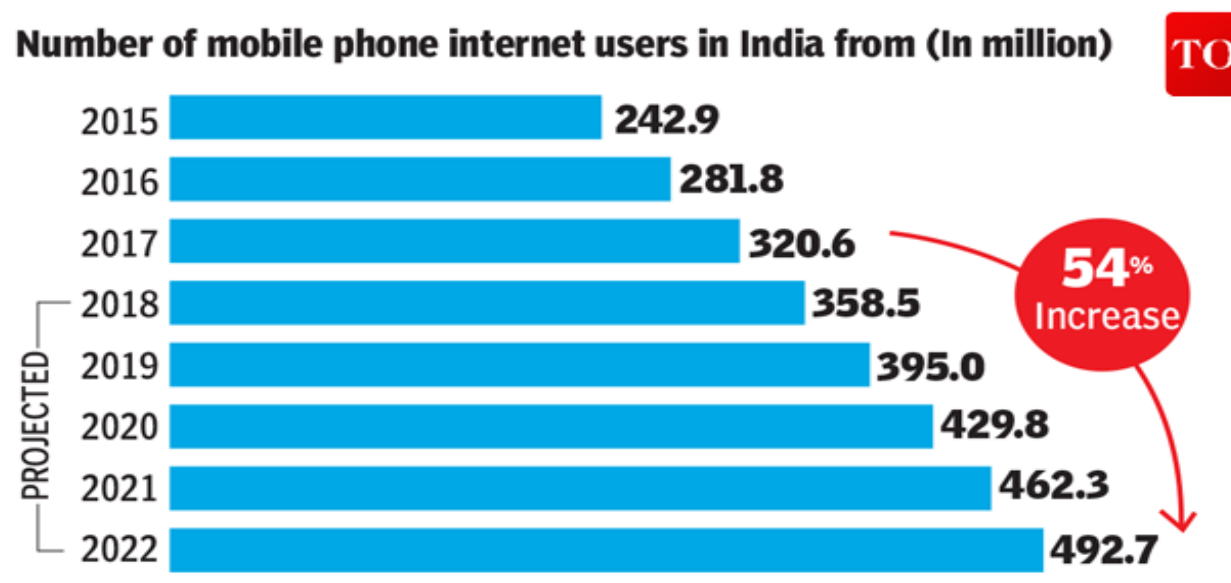

Figure 1: Mobile Internet Users

Millennials, Generally, the term millennials are well-thought-out to spread everywhere in the switch of the 21 st decade to individuals who have reached adulthood. Millennials matured in increasing internet and socially networked globe packed with electronics Millennials contribute in a large manner to mobile shopping, and they're continuing to the shop stagnant errand. For e-retailers, the technological revolution has had the most standard commercial exposure. According to a pew research institute, this team has become the leading staying millennium in the U.S. with far more than 75.4 million employees, and it is expected that migration will increase this amount to 81.1 million by 2036 . Harris et al. (2011), Millennials are summarized in the use of technology as being the most practical generation. The platform allows shopping, learning, connecting and socializing. The previous research suggests that millennial generation is considerably different from the previous generation in traditional business dealing out assuming efficiency, average service interaction, and average or lower expensive product value without brand identity, brand development, or extended-term product quality. Approximately (22\%) millennial buying was also biased by their friends ' social activity. Like other customers of mobile trade-in research, the dimension of millennials for offers, of regular visits to shop destinations for shopping online and comparison. Even though the market website's early stages should be replaced by many alleged traditional purchases, which resulted in an approximate grade. Eventually, Wireless twisted shopping in a non-stop procedure. Recent research indicated that 70 percent of millennials shop online to save time, 60 percent of them, it is a substance of convenience, and 40 percent it is about exceeding. Millennials try to create rapid buying choices, associate baby boomers, shop for comfort and then efficiency. Bounkhong et al. (2017), the perceived ease of use, usefulness, and enjoyment of social trade ensured a significant effect on the behavior and attitude toward intentions of millennials of using social trade in garments purchasing. Thomas (2018), the interdependence of millennials has been a consequence of the knowledge they also undergone in different ways, such as life experiences, common experiences and shared beliefs. Decision making becomes one of the key characteristics that play a significant part in distinguishing themselves among in today's generations.

\section{LITERATURE REVIEW}

Iyer et al. (2016), identified that demographic characteristics such as gender affected perceptions of the value of advertising and the informativeness of advertising. Bounkhong et al. (2017), enjoyment had a much stronger impact on attitude. Makhitha (2014), the perceptions towards online shopping did not diverge among Generation Y students in distinct age groups. It was discovered that the perceived comfort associated with shopping online affected the learners of Generation Y. With the exception of website design, reliability, customer service, and trust, online shopping has been revealed to have an effect on consumer behaviour. Bounkhong and Cho (2017), observed factors influencing the intentions of millennials of using social trade in apparel shopping through adopting the acceptance of the technology model.

Choudhary and Choudhary (2013), it is supposed that user trust will play an essential role in the recognition and prevalent disposition of mobile commerce applications. Muthukumar and Muthu (2015), investigated that people between the ages of 18 and 34 are very likely to use their wireless devices as a shopping instrument. Hillman and Neustaedter (2017), the study examines classic m-Commerce habits and behaviours as well as trust issues due to its lengthy-term e-Commerce interest. The findings showed that people shopping on mobile devices everyone has even 
several concerns about trust. Whereas problems of trust arise together with challenges of repurchasing anxiety and mental model.

Brown and Kim (2017), examines the use of digital purchasing by Millennials and the desire to buy mobile devices when taking into account perceived financial risks, social impact, convenience, and satisfaction. Results stated that social influence has not had a significant impact on the intention of using mobile devices for shopping but has a significant impact on the actual intent to buy mobile devices. The perceived financial risk did not seem to affect the intentions of shopping with mobile devices. The findings revealed that convenience is a strong indicator of mobile device purchase intention. Beak (2013), put forth that two primary constructs: one is the intrinsic determinants of the user - value, innovativeness, gender, well-being and superordinate influence - on the attitude toward using mobile applications, and the other is the relationship between the attitude and the desire to buy and repurchase apps, and the factors that influence this relationship. Value, innovation, and superordinate impact are recognized to impact the attitude in the quantitative study consequence. Furthermore, satisfaction enhanced the relationship between the intention to buy and buyback.

Lee and Wong (2016), Identified ways of measuring mobile business customer loyalty in Malaysia by incorporating quality e-service models and mobile business connection theories. They also inspect relationships between effectiveness, system accessibility, fulfilment and privacy dimensions of e-service quality and relationship quality dimensions of satisfaction, trust and dedication to customer loyalty in mobile business operations. Yaseen and Zayed (2010), applied TAM model they identified variables such as Perceived trust, perceived usefulness, perceived ease of use, social and cultural values, and economic problems to address mobile trade factors and the outcomes reveal that perceived trust, perceived usefulness, perceived ease of use, social and cultural values are significantly related to the purpose of setting up mobile trade technology whereas financial problems are not important.

\section{THEORETICAL BACKGROUND}

\section{TECHNOLOGY OF ACCEPTANCE MODEL}

The Technology Acceptance Model (TAM) developed by Davis in 1989, it is one of the most powerful models for the determination and enlightenment of technology user acceptance. Entrenched in the Theory of Reasoned Action (TRA) by Fishbein and Ajzenin the year 1975, the causal relationship between convictions and attitude constructs was explored by TAM. In particular, the model speculates that two convictions about new technology, perceived usefulness (PU) and perceived ease of use (PEOU), determine the attitude of a person (ATT) towards the use of a technology model. Bounkhong et al. (2017) the TAM elucidates that the behaviors of an individual person acceptance of information technology are defined by five parameters counting with perceived ease of use, usefulness, and enjoyment; and attitude and intent using information technology.

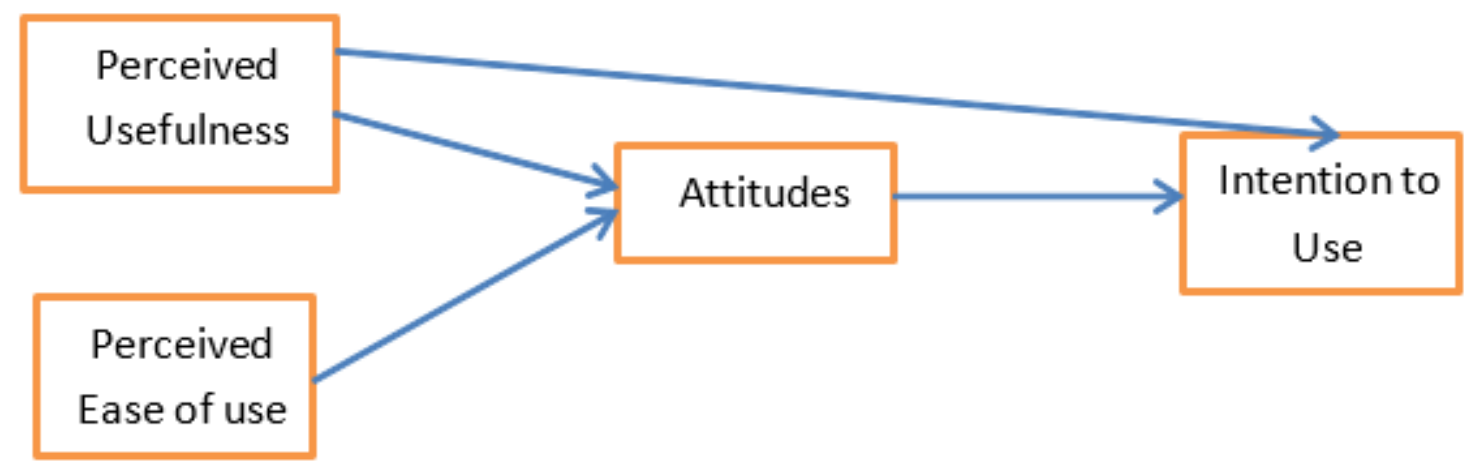

Figure 2: Technology Acceptance Model from He, wang and Liu (2012)

\section{UNIFIED THEORY OF ACCEPTANCE AND USE OF TECHNOLOGY (UTAUT2)}

Venkatesh et al. (2003) originally developed the UTAUT model which was expounded employee technology acceptance and use, the advanced model is extended to another context. UTAUT2, Venkatesh et al. (2012) lengthen his model through ascertaining fundamental added variables and relations to be combined keen on UTAUT, from a consumer perspective.

\section{MODEL DEVELOPMENT}

TAM plus UTAUT2 have their deficiencies; we need to incorporate the two models into one to enrich theirs's methodical power, developing information technology in a marketing context. Some researchers have created a few endeavors for IS implementation in the electronic commerce sector, but there is a drought of studies in mobile commerce. For mobile commerce attitude influence on millennials, purchase intention is more ignorant, because mobile commerce has more features which traditional electronic commerce does not have, those exclusive topographies will improve mobile commerce business. Thus, in the present study, we substitute intention to use with purchase intention in 
the model of the TAM. In the combination of TAM as well as UTAUT2 model, that performance expectancy, facilitating condition, social influence and attitude on purchase intention.

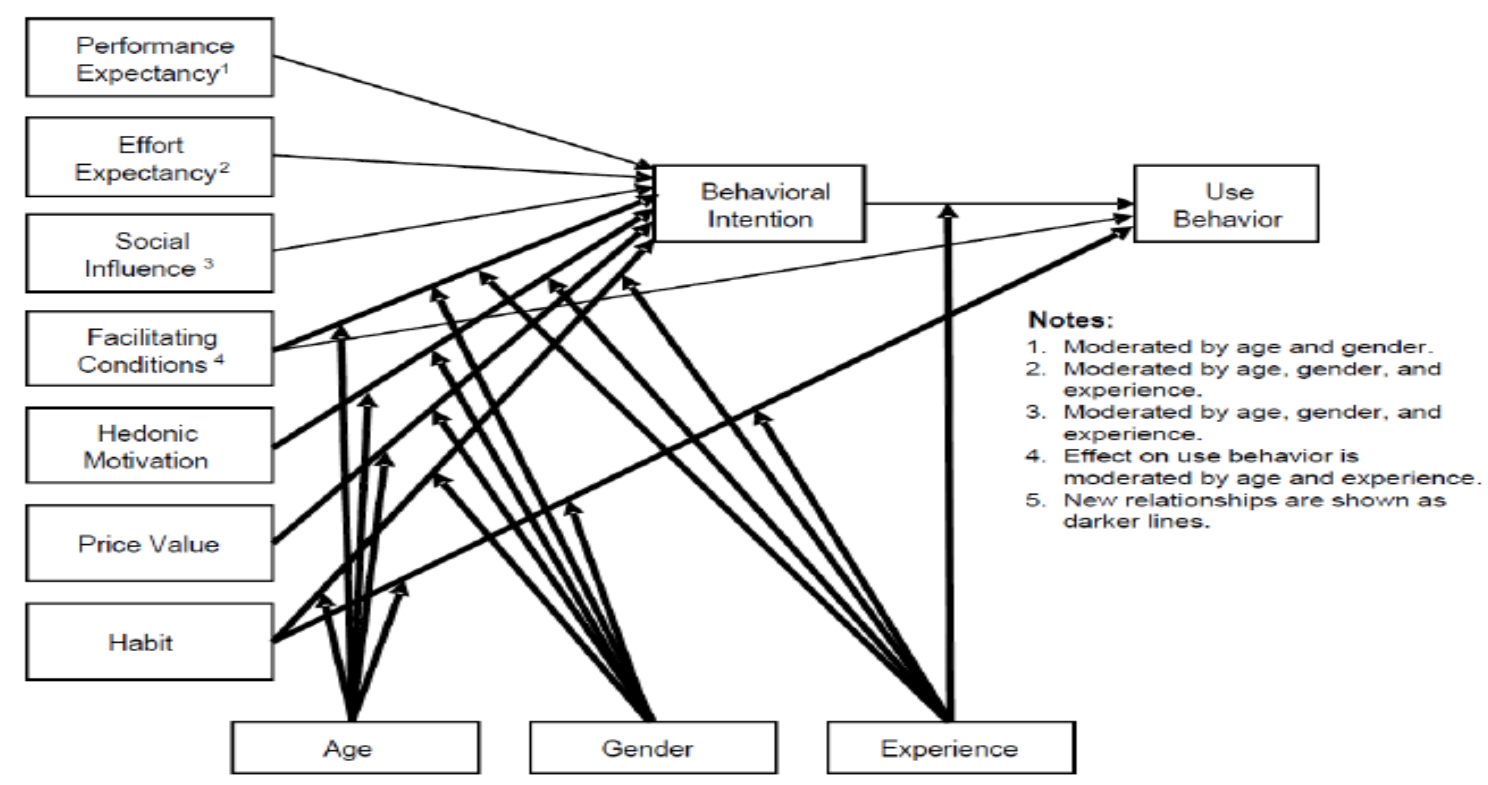

Figure 3: Unified Theory of Acceptance and Use of Technology (UTAUT2) (2012)

\section{RESEARCH QUESTIONS}

- Does millennial's attitude of mobile shopping have a direct effect on purchase intention?

- Does the integrate TAM and UTAUT2 model will have a significant effect on attitude towards purchase intention among millennials mobile purchase?

- Which product is mostly preferred by millennials to place orders by using mobile internet?

\section{RESEARCH OBJECTIVES}

- To study the use of mobile technology and integrate the TAM and UTAUT2 models to identify the attitude of the millennial towards purchase intention in mobile shopping.

- To study the construct this is highly influencing the millennials in point of mobile purchase.

- To investigate the factor which is highly motivated the students while going for mobile food purchase.

\section{HYPOTHESIS DEVELOPMENT}

The present research targets to explore the behavior towards the adoption of millennials' mobile purchase intention. Based on the research questions and objectives the following hypothesis is developed:

- H1: Performance expectancy has a positive effect on attitude on millennials' mobile commerce context.

- H2: The facilitating condition has a positive effect on attitude towards millennials' purchase intention on mobile purchases.

- H3: Social impact has a positive effect on the attitude towards the buy intention of millennials.

- H4: Attitude has a positive effect on buying intention among millennials on mobile purchasing.

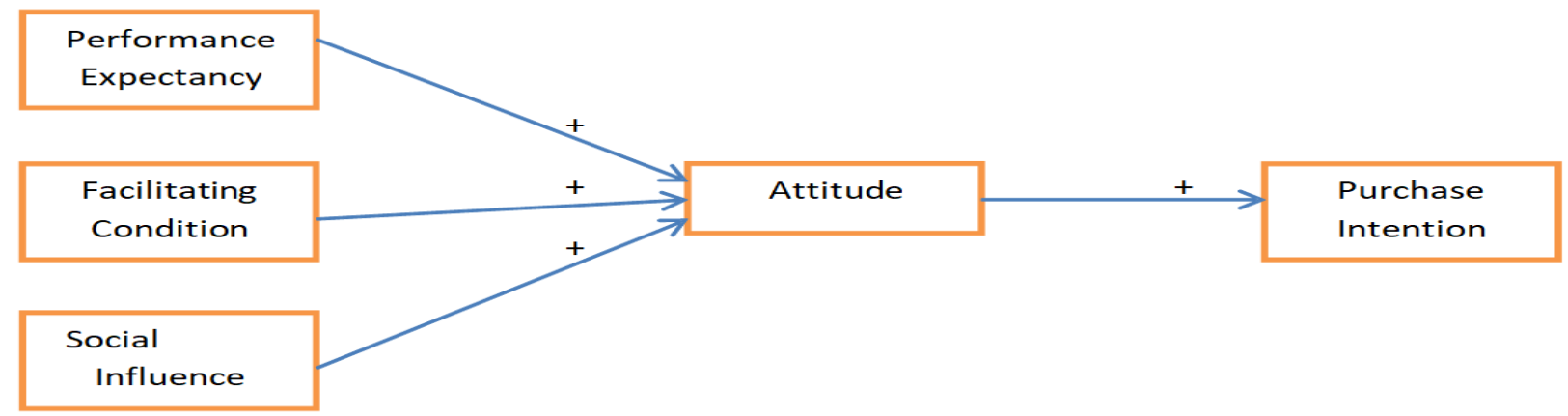

Figure 4: Research Model, Developed by authors 


\section{CONSTRUCTS AND ITS OPERATIONAL DEFINITION}

Performance expectancy: In carrying out certain operations, the extent to something that the use of technology might provide advantages for customers. Malik et al. (2017), an immediate impact on satisfaction if customers embrace technology leading to continuous application. As an imperative factor for acceptance and unhindered use, male consumers discovered performance expectancy.

Facilitating condition: It indicates the income and livelihood perspectives available to buyers for executing behaviour. Malik et al. (2017), users have enough skills and resources they can use the technology. This developed equally an essential element from this cluster and it has approximately negative on its role in technology adoption.

Social influence: The quantity that customers perceive as important others (e.g. family and friends) thinks they should use a specific technology.

Purchase Intention: Generally, purchase intention is the degree which consumer likes to purchase on specific product or services. Purchase intention shows the hollow of customer retention.

Attitude: It is a multidimensional construct involving networks of interconnected beliefs and evaluations. With increasing direct experience, individuals are expected to rely less on others and more on their attitude.

\section{METHODOLOGY}

\section{QUESTIONNAIRE DESIGN}

A sampling technique was considered suitable to investigate the attitude of these studies millennials in a mobile shopping context. A purposive sampling method was used. An online questionnaire study with a 5-point Likert scale ranging from (1-Strongly Disagree, 2-Disagree, 3-Neutral, 4-Agree, and 5-Strongly Agree) was implemented using a quantitative research strategy to assess the dependent variable and independent variables of previous study studies in the study (He, wang and Liu 2012, Venkatesh et al. 2012). Demographic data of the participants were also gathered to investigate if gender, age, marital status, and academic level impact buying intention to use mobile phones for buying millennials. Data have been collected from 533respondents online. The questionnaire includes the frequency of using a mobile phone, experience of respondents, product purchased by the millennials by using a mobile phone, etc. All the collected data have been tested for reliability and validity presented for further analysis.

\section{TECHNIQUES USED TO ANALYSE DATA}

Based on the information gathered we used SEM (Structural Equation Model) - smart PLS 2.0 software to validate the theoretical model. Because of our sample size (533), it is suitable for us to use covariance as an analysis basis software to validate the model. In general, PLS is more suitable for small sample analysis also, PLS-SEM is a structural equation modeling technique that makes it possible to estimate complicated cause-effect association models with latent variables.

\section{ANALYSIS AND INTERPRETATION}

\section{RELIABILITY AND VALIDITY}

To verify the construct validity and the determinants composing factors reliability, smart PLS 2.0 analysis is used. It is used for convenient statistical analysis method for the path analysis, and show the reliability and validity simultaneously with the various test result. First of all, all the components of each variable are fully met the composite validity standard index through appearing more than 0.70-factor loading. Besides, AVE index is showed more than 0.70 except the performance expectancy variable it showed that 0.6 . R2 value of attitude is 0.5074 and purchase intention is 0.468 . The reliability is also verified with C.R. (more than 0.80) and Cronbach's Alpha (more than 0.70). Each validity and reliability measures are satisfied and it has good internal consistency, the test result is shown the following table 1.

Table 1: Reliability and Validity test result

\begin{tabular}{lllll}
\hline & AVE & Composite Reliability (CR) & R2 & Cronbach's Alpha \\
\hline ATT & 0.7672 & 0.9294 & 0.5074 & 0.8988 \\
\hline FC & 0.7582 & 0.9261 & & 0.8936 \\
\hline PE & 0.7904 & 0.9378 & & 0.9113 \\
\hline PI & 0.6890 & 0.8661 & 0.4678 & 0.7725 \\
\hline SI & 0.7192 & 0.8847 & & 0.8054 \\
\hline
\end{tabular}

From table 3 we could see that factor loads measuring important structure variable problems are all above 0.7 and $70 \%$ of the variance is described in the latent variable. The cumulative elucidated variance of the derived factor is generally thought to be more relevant when it is $70 \%$ to $80 \%$.

As illustrated in table 4, the AVE square root of each factor is bigger than the respective correlation coefficient, thus having excellent validity between distinct variables. We need the square root of AVE values to check the validity of the identification. If the AVE's square root is larger than the correlation with the other variables, suggesting a strong 
discriminating validity of the measurement model.

Table 2: Descriptive statistics (Sample Size, $n=132$ )

\begin{tabular}{|c|c|c|c|}
\hline Item & Category & Frequency & Percentage \\
\hline \multirow[t]{2}{*}{ Gender } & Male & 333 & 62.5 \\
\hline & Female & 200 & 37.5 \\
\hline \multirow{3}{*}{ Age } & $18-21$ & 221 & 41.5 \\
\hline & $22-25$ & 305 & 57.2 \\
\hline & Above 25 & 7 & 1.3 \\
\hline \multirow{4}{*}{ Family Income } & Below 20000 & 65 & 12.2 \\
\hline & $20001-40000$ & 153 & 28.7 \\
\hline & $40000-60001$ & 195 & 36.6 \\
\hline & Above 60000 & 120 & 22.5 \\
\hline \multirow[t]{2}{*}{ Graduation } & UG & 297 & 55.7 \\
\hline & PG & 236 & 44.3 \\
\hline \multirow{4}{*}{ Using mobile internet for shopping } & Rarely & 42 & 7.9 \\
\hline & Every once in a while & 58 & 10.9 \\
\hline & Sometimes & 106 & 19.9 \\
\hline & Always & 327 & 61.4 \\
\hline \multirow{5}{*}{ Mode of payment } & Cash on delivery & 211 & 39.6 \\
\hline & Credit card & 11 & 2.1 \\
\hline & Debit card & 125 & 23.5 \\
\hline & Online banking & 105 & 19.7 \\
\hline & Paytm & 81 & 15.2 \\
\hline \multirow{3}{*}{ Information source } & Media & 96 & 18.0 \\
\hline & Personal effects & 201 & 37.7 \\
\hline & Friends & 236 & 44.3 \\
\hline \multirow{5}{*}{ Purchase product } & Electronic items & 225 & 42.2 \\
\hline & Clothing apparel & 41 & 7.7 \\
\hline & Stationary items & 213 & 40.0 \\
\hline & Household appliances & 9 & 1.7 \\
\hline & Furniture & 45 & 8.4 \\
\hline \multirow{6}{*}{ Factors } & Security & 316 & 59.3 \\
\hline & User friendly & 92 & 17.3 \\
\hline & Easy to access & 71 & 13.3 \\
\hline & Complete catalogue & 28 & 5.3 \\
\hline & Online product supportCustomer reviews & 8 & 1.5 \\
\hline & & 18 & 3.4 \\
\hline
\end{tabular}

Table 3: Cross Loadings

\begin{tabular}{llllll}
\hline & ATT & FC & PE & PI & SI \\
\hline ATT1 & 0.8771 & 0.5461 & 0.5878 & 0.5740 & 0.3836 \\
\hline ATT2 & 0.8836 & 0.5243 & 0.5697 & 0.5733 & 0.4637 \\
\hline ATT3 & 0.8878 & 0.5052 & 0.5307 & 0.5868 & 0.3240 \\
\hline ATT4 & 0.8549 & 0.5819 & 0.5860 & 0.6560 & 0.3232 \\
\hline FC1 & 0.5613 & 0.8900 & 0.5386 & 0.5688 & 0.4732 \\
\hline FC2 & 0.5469 & 0.9005 & 0.5234 & 0.5318 & 0.4602 \\
\hline FC3 & 0.5759 & 0.8711 & 0.5567 & 0.5428 & 0.4486 \\
\hline FC4 & 0.4544 & 0.8193 & 0.4918 & 0.5230 & 0.3790 \\
\hline PE1 & 0.5795 & 0.5910 & 0.8817 & 0.5056 & 0.3381 \\
\hline PE2 & 0.5696 & 0.5190 & 0.9070 & 0.5351 & 0.4221 \\
\hline PE3 & 0.5756 & 0.4955 & 0.9101 & 0.5056 & 0.3782 \\
\hline PE4 & 0.5865 & 0.5511 & 0.8564 & 0.5297 & 0.3428 \\
\hline PI1 & 0.6806 & 0.5695 & 0.5131 & 0.9150 & 0.3626 \\
\hline PI2 & 0.6180 & 0.5908 & 0.5798 & 0.9145 & 0.4027 \\
\hline PI3 & 0.3308 & 0.3477 & 0.3250 & 0.6274 & 0.3499 \\
\hline SI1 & 0.3436 & 0.3876 & 0.3855 & 0.2875 & 0.8220 \\
\hline SI2 & 0.3293 & 0.4132 & 0.3262 & 0.3798 & 0.8548 \\
\hline SI3 & 0.4035 & 0.4828 & 0.3483 & 0.4374 & 0.8667 \\
\hline
\end{tabular}


Table 4: Latent variable correlation coefficient

\begin{tabular}{llllll}
\hline & ATT & FC & PE & PI & SI \\
\hline ATT & 1.0000 & & & & \\
FC & 0.6175 & 1.0000 & & & \\
PE & 0.6503 & 0.6069 & 1.0000 & & \\
PI & 0.6840 & 0.6218 & 0.5840 & 1.0000 & \\
SI & 0.42613 & 0.5079 & 0.4381 & 0.4381 & 1.0000 \\
\hline
\end{tabular}

\section{PATH MODEL}

Figure 5 illustrates that the four hypotheses operated by PLS, where the variable is independent Purchase Intention $\mathrm{R} 2=0.468$. In general, we can say that when the value of R2 is above 0.3, the interpretation from model to dependent variable is powerful. Precisely, the lines that PE-ATT $\left(b=0.421,{ }^{*} \mathrm{P}<0.05\right)$, FC-ATT $\left(b=0.316,{ }^{*} \mathrm{P}<0.05\right)$ and SI-ATT $\left(\mathrm{b}=0.090,{ }^{*} \mathrm{P}<0.05\right)$ is proved, hypothesis 1,2 and 3 are supported. The line that ATT-PI $\left(\mathrm{b}=0.684,{ }^{*} \mathrm{P}<0.05\right)$ are also positively significant, which means hypothesis 4 is supported.

The $t$ value has been shown in Table 5. The last row of Table 5, all $\mathrm{t}$ value is above $1.96(* \mathrm{P}<0.05)$ except social influence variable, its $t$ value is 0.9367 , it means that this routine quotient is significant when $\mathrm{P}=0.05$, so it confirms hypothesis 1, 2 and 4 have a positive impact on the intention to buy of millennials attitude towards mobile shopping and hypothesis 3 have a less significant effect on it.

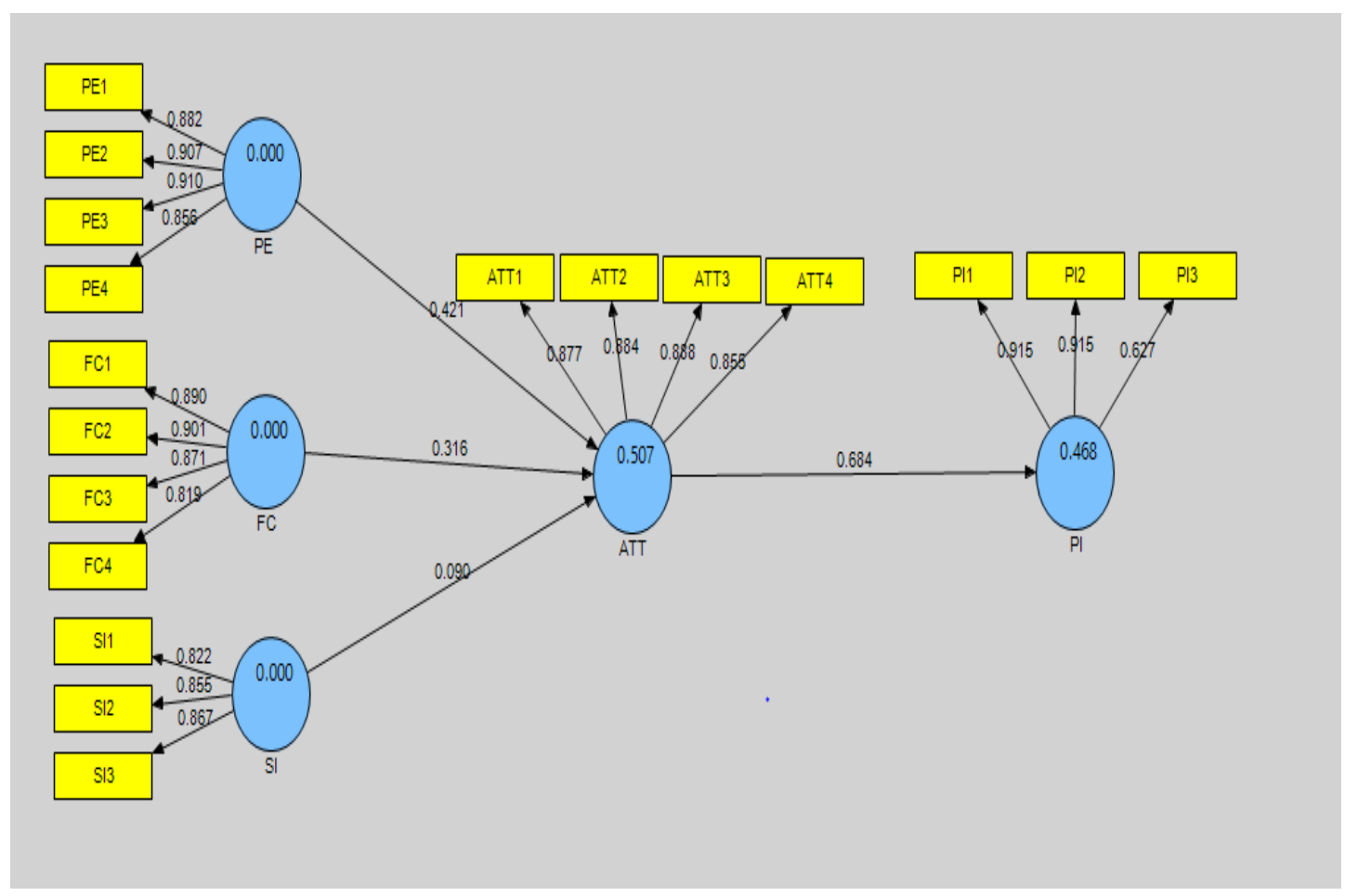

Figure 5: PLS Analysis Results

Table 5: Significance of path coefficient

\begin{tabular}{llllll}
\hline Hypotheses & $\begin{array}{l}\text { Original } \\
\text { Sample }(\text { OS) }\end{array}$ & $\begin{array}{l}\text { Sample } \\
\text { Mean }\end{array}$ & $\begin{array}{l}\text { Standard } \\
\text { Deviation }\end{array}$ & $\begin{array}{l}\text { Standard } \\
\text { Error }\end{array}$ & t value \\
\hline $\mathrm{H}_{1}: \mathrm{ATT} \rightarrow$ PI & 0.6840 & 0.6880 & 0.0721 & 0.0721 & 9.4890 \\
\hline $\mathrm{H}_{2}: \mathrm{FC} \rightarrow$ ATT & 0.3162 & 0.3164 & 0.1190 & 0.1190 & 2.6567 \\
\hline $\mathrm{H}_{3}: \mathrm{PE} \rightarrow$ ATT & 0.4208 & 0.4202 & 0.0968 & 0.0968 & 4.3489 \\
\hline $\mathrm{H}_{4}: \mathrm{SI} \rightarrow$ ATT & 0.0903 & 0.0943 & 0.0964 & 0.0964 & 0.9367 \\
\hline
\end{tabular}

\section{RESULTS AND DISCUSSION}

This research investigates the attitude of the millennial towards mobile shopping. We adopted a mobile shopping context and integrated model based on TAM and UTAUT2 theory, using PLS software analysis to test with 533 samples data collected from an online survey. The results of this research show that most of the students were male represented by 62.5 percent $(\mathrm{N}=533)$. From the descriptive statistics the majority of the millennials using mobile internet always. They prefer mode of payments as cash on delivery as 39.6 percent, the other payment options like a credit card, online payment, Paytm, etc. Over 44.3 percent $(\mathrm{N}=533)$ of the respondents seeking information regarding their purchase from their friends. The products mostly purchased by the millennials via mobile phones as electronic items as 42.2 percent 
followed by stationery items, household appliances, clothing apparel, and furniture. This research we identify factors as security, ease to access, complete catalog, customer reviews, online product support from that 59.3 percent of the respondents chosen security is the primary option to go for mobile purchase. Performance expectancy and facilitating conditions have a strong influence on millennials' attitudes toward using a mobile device for shopping. But social influence has fewer attitudes to millennials' attitudes towards purchase intention in mobile shopping.

\section{CONCLUSION}

Mobile commerce has the attraction of both retailers and customers. Particularly this research activity on mobile commerce has increased the significance of millennials' purchase intention. With the effect of mobile shopping, millennials can interact with the business in a hassle-free manner and this element of marketing can help mobile shopping businesses in marketing strategies and boosting customer satisfaction and increase customer loyalty.

This study offers a new landscape for retail business Persons to study the attitude of millennials in mobile trade adoption, and that would have an executive position in forecasting the purchase intention of respondents. The practical consequences of this research are that it offers a theoretical basis for mobile company providers to promote their products and services, helping them to develop an extremely effective marketing strategy to encourage consumers to effectively using the mobile company. It is considered a priority for marketers to know the reasons behind the purchasing intention of millennials towards mobile purchases.

\section{LIMITATION AND STUDY FORWARD}

This work provides a general overview of millennials' attitudes towards on purchase intention in mobile shopping context it is restricted to both geographically and demographically, owing to the present and expected buy intention of millennials, the demographic sample may be more essential. Further research is needed extending demographic study as a moderate variable identifying the power of the variable affecting the attitude towards the purchase intention of millennials at the stage of the mobile purchase and the importance of culture could also be added to ever more studies in this region.

\section{ACKNOWLEDGMENT}

The authors confirm that the data do not contain any conflict of interest.

\section{REFERENCES}

1. Baek, Y. (2013). Analysis of user's attitude toward apps, intention to use and continual consuming intentionFocused on mobile commerce. International Journal of Contents, 9(4), 35-44. https://doi.org/10.5392/IJoC.2013.9.4.035

2. Bounkhong, T., \& Cho, E. (2017).Factors affecting millennials' intentions to use social commerce in fashion shopping. The Research Journal of the Costume Culture, 25(6), 928-942. https://doi.org/10.29049/rjcc.2017.25.6.928

3. Bounkhong, T., Cho, E., \& Smith, K. R. (2017). Are Millennials Willing to Use Social Commerce in Apparel Shopping? International Textile and Apparel Association, Inc., 1-3: ITAA Proceedings. https://doi.org/10.31274/itaa proceedings-180814-1795

4. Brown, B., \& Kim, J. (2017).Understanding Millennials Mobile Shopping Behaviors: An Implication for Insurance Industry. The Journal of International Management Studies, 12(1), 71-82.

5. Choudhary, S., \&Choudhary, N. (2013).Role of M-commerce in today's scenarios. EXCEL International Journal of Multidisciplinary Management Studies, 3(7), 252-260.

6. Harris, K. J., Stiles, J., \& Durocher, J. (2011). A preliminary evaluation of the millennial shopping experience: Preferences and plateaus. Hospitality Review, 29(1), 24-47.

7. He, T., Wang, Y., \& Liu, W. (2012). Empirical Research on Mobile Commerce Use: an Integrated Theory Model. Advances in Information Sciences and Service Sciences, 4(7), 23-32. https://doi.org/10.4156/aiss.vol4.issue7.3

8. Hillman, S., \& Neustaedter, C. (2017).Trust and mobile commerce in North America. Computers in Human Behavior, 70, 10-21. ttps://doi.org/10.1016/j.chb.2016.12.061

9. Iyer, R., Eastman, J. K., \& Monteiro, H. (2016).Perceptions of millennials' media attitudes and use: a comparison of us and Indian millennials. Marketing Management, 69-85.

10. Jay Sang Ryu. (2013). Mobile marketing communications in the retail environmet: A comparision of QR code users and non-users. Mobile Marketing Association IJMM winter, 8(2), 19-29.

11. Lee, C.-S., \& Ho, J. C. (2010).A framework for analyzing business model innovation in mobile commerce. Journal of International Technology and Information Management, 19(4), 3.

12. Lee, K. C., Lee, S., \& Kim, J. S. (2005). Analysis of mobile commerce performance by using the tasktechnology fit Mobile Information Systems (pp. 135-153): Springer. https://doi.org/10.1007/0-387-22874$\underline{8 \quad 10}$

13. Lee, W. O., \& Wong, L. S. (2016).Determinants of mobile commerce customer loyalty in Malaysia. Procedia-Social and Behavioral Sciences, 224, 60-67. https://doi.org/10.1016/j.sbspro.2016.05.400 
14. Makhitha, K. (2014). Factors influencing generations Y students' attitude towards online shopping. Mediterranean Journal of Social Sciences, 5(21), 39-50. https://doi.org/10.5901/mjss.2014.v5n21p39

15. Malik, A., Suresh, S., \& Sharma, S. (2017). Factors influencing consumers' attitude towards adoption and continuous use of mobile applications: a conceptual model. Procedia computer science, 122, 106-113. https://doi.org/10.1016/j.procs.2017.11.348

16. Muthukumar, S., \& Muthu, N. (2015). The Indian kaleidoscope: emerging trends in M-Commerce. International Journal of Advanced Research in Computer and Communication Engineering, 4(1), $50-56$. https://doi.org/10.17148/IJARCCE.2015.4110

17. Ngai, E. W., \& Gunasekaran, A. (2007).A review for mobile commerce research and applications. Decision support systems, 43(1), 3-15. https://doi.org/10.1016/j.dss.2005.05.003

18. Pascual Marimón, P., Mollá Descals, A., \& Frasquet, M. (2015).Internal factors predisposing the consumer to be a multichannel shopper. Esic Market Economics and Business Journal, 46(3), 101-134. https://doi.org/10.7200/esicm.152.0463.3i

19. Thomas, M. R., Kavya, V., \& Monica, M. (2018).Online website cues influencing the purchase intention of generation $\mathrm{z}$ mediated by trust. Indian Journal of Commerce and Management Studies, 9(1), 13-23. https://doi.org/10.18843/ijcms/v9i1/03

20. V. Venkatesh, J.Y. Thong, X. Xu (2012). Consumer acceptance and use of information technology: extending the unified theory of acceptance and use of technology. MIS Q., 36 (1) (2012), pp. 157-178. https://doi.org/10.2307/41410412

21. Venkatesh, V., Morris, M. G., Davis, G. B., \& Davis, F. D. (2003). User acceptance of information technology: Toward a unified view. MIS Quarterly, 27(3), 425-478. https://doi.org/10.2307/30036540

22. Yaseen, S. G and Zayed (2010). Exploring critical determinants in deploying mobile commerce technology. American Journal of Applied Sciences, 7(1), 35-46. https://doi.org/10.3844/ajassp.2010.120.126 